\title{
Two common species dominate the species-rich Euglossine bee fauna of an Atlantic Rainforest remnant in Pernambuco, Brazil
}

\author{
R. Oliveira ${ }^{a *}$, C. E. Pinto ${ }^{b}$ and C. Schlindwein ${ }^{c}$ \\ aDepartamento de Biodiversidade, Evolução e Meio Ambiente, Universidade Federal de Ouro Preto - UFOP, \\ Campus Morro do Cruzeiro, Bauxita, CEP 35400-000, Ouro Preto, MG, Brazil \\ 'Programa de Pós-Graduação em Entomologia, Faculdade de Filosofia, Ciências e Letras de Ribeirão Preto, Universidade \\ de São Paulo - USP, Av. Bandeirantes, 3900, Monte Alegre, CEP 14040-030, Ribeirão Preto, SP, Brazil \\ 'Departamento de Botânica, Universidade Federal de Minas Gerais - UFMG, Av. Antônio Carlos, 6627, \\ Pampulha, CEP 31270-901, Belo Horizonte, MG, Brazil \\ *e-mail: reislaxoliveira@gmail.com
}

Received: February 20, 2014 - Accepted: August 19, 2014 - Distributed: November 30, 2015

(With 3 figures)

\begin{abstract}
Nowadays, the northern part of the Atlantic Rainforest of Brazil is largely destroyed and forest remnants rarely exceed 100 ha. In a 118 ha forest fragment within a state nature reserve of Pernambuco (Reserva Ecológica Gurjaú), we surveyed the orchid bee fauna (Apidae, Euglossini) using eight different scent baits to attract males. Once a month during one year, the bees were actively collected with entomological nets, from November 2002 to October 2003 by two collectors. We collected 2,908 orchid bee males belonging to 23 species, one of the highest richness values of the Northern Atlantic Rainforest. Bees of only two species, Euglossa carolina (50\%) and Eulaema nigrita (25\%), which occurred throughout the year, accounted for three quarter of the collected individuals. Both species are typical for open or disturbed areas. Rainforest remnants like those of Gurjaú within the predominant sugar cane monocultures in the coastal plains of the northern Atlantic Rainforest play an important role in orchid bee conservation and maintenance of biodiversity.
\end{abstract}

Keywords: bees, conservation, biological diversity, Euglossini, Euglossa carolina, Eulaema nigrita.

\section{Duas espécies comuns dominam a rica fauna de Euglossini em um remanscente de Floresta Atlântica em Pernambuco, Brasil}

\begin{abstract}
Resumo
Atualmente, a porção norte da Floresta Atlântica brasileira está drasticamente destruída e os remanescentes florestais raramente excedem 100 hectares. Com uso de iscas odoríferas atrativas aos machos, amostramos a fauna de abelhas-das-orquídeas (Hymenoptera: Apidae: Euglossini) em um fragmento florestal de 118 ha na Reserva Ecológica de Gurjaú, Pernambuco. As abelhas foram ativamente coletadas com redes entomológicas por dois coletores, uma vez por mês, de novembro de 2002 a outubro de 2003. Coletamos 2908 machos de Euglossini pertencentes a 23 espécies, um dos mais altos valores de riqueza registrados para a Floresta Atlântica nordestina. Três quartos das abelhas coletadas pertenceram a apenas duas espécies, Euglossa carolina (50\%) and Eulaema nigrita (25\%), típicas de áreas abertas e perturbadas e ativas ao longo de todo ano. Remanescentes de floresta como os de Gurjaú, em meio às monoculturas de cana-de-açúcar, podem desempenhar um importante papel na conservação das abelhas-das-orquídeas em ambientes fragmentados como os da Mata Atlântica do nordeste do Brasil.
\end{abstract}

Palavras-chave: abelhas, conservação, diversidade biológica, Euglossini, Euglossa carolina, Eulaema nigrita.

\section{Introduction}

Orchid bees (Apidae, Euglossini) are found exclusively in the Neotropics, where they play an important role as pollinators of numerous nectar, pollen, resin and perfume flowers in their ecosystems, especially in rainforest habitats (Dressler, 1982; Schlindwein, 2000; Roubik and Hanson, 2004). They are outstanding insects due to the vivid and brilliant metallic colors of most species, as well as to the conspicuous behaviour of the males, which collect fragrances from flowers of hundreds of plant species, especially orchids, and some other sources (Vogel, 1966; Dodson et al., 1969). The fragrances are stored in hind leg cavities and supposedly used during mating (Vogel, 1963; 
Kimsey, 1980; Dressler, 1982; Eltz et al., 1999). According to Ackerman (1989) and Eltz et al. (2005), the blends of collected fragrances by males seem to be species-specific.

To date, approximately 50 pure synthetic compounds that make part of the floral bouquet of their perfume flowers are known to attract male euglossine bees (Roubik and Hanson, 2004). A part of these substances have been used on bating assays, which addressed questions on orchid bee diversity and geographic distribution (e.g. Ackerman, 1983; Janzen et al., 1982; Peruquetti et al., 1999; Nemésio, 2009), population ecology (e.g. Roubik, 2001), chemical ecology (e.g. Eltz et al., 1999, 2005) and conservation (Powell and Powell, 1987; Tonhasca et al., 2002; Nemésio and Silveira 2007a, 2010).

The Atlantic Forest north of the São Francisco river, also called Center of Endemism Pernambuco (hereafter $\mathrm{CEP}$ ), comprises a rich euglossine fauna. Compared to other areas in the Atlantic Forest domain, CEP is the most devastated and the least protected one (Silva and Tabarelli, 2001). Originally the forest ranged from the state of Rio Grande do Norte to the state of Alagoas covering a total area of almost $60,000 \mathrm{~km}^{2}$. Nowadays, more than $95 \%$ of the Atlantic Forest has been cleared and the remaining forest area is scattered in small fragments, $80 \%$ of them smaller than 50 ha (Ribeiro et al., 2009).

The CEP is the habitat of over $50 \%$ of all birds occurring in the Brazilian Atlantic forest. In addition this narrow strip of coastal forest houses endemic species of birds, woody plants, bromeliads, frogs and butterflies (Silva and Tabarelli, 2000, 2001). Among the endemic insects are the orchid bee species Euglossa perpulchra, Eulaema felipei Nemesio 2010 and Eufriesea pyrrhopyga Faria \& Melo 2011 (Moure and Schlindwein, 2002; Nemesio, 2010; Faria and Melo, 2011). Thus, CEP deserves consideration with respect to local orchid bee species richness, species distribution and composition.

Considering that most orchid bee species are forest dependent key pollinators, the conservation of these bees is crucial for maintenance of forest biodiversity. Therefore, it is necessary to acquire information on the faunistic composition and abundance of euglossine bees of forest remnants, especially in the northern part of the Atlantic Forest. Thus, the main goal of the present study was to inventory the orchid bee fauna of a forest remnant in CEP in order to assess its species richness and composition. Moreover, we discuss ecological characteristics of the most common species in the assemblage.

\section{Material and Methods}

\subsection{Study site}

The study was conducted at the Reserva Ecológica Gurjaú (hereafter Gurjaú), located in the municipalities of Cabo de Santo Agostinho, Jaboatão dos Guararapes and Moreno, state of Pernambuco, Brazil. The reserve originates from dispossessed sugar cane farms in the early 20th century in order to supply water to the state capital. Currently, together with the Catende complex, the area is considered a priority for conservation of Atlantic forest north of the Rio São Francisco (Pôrto et al., 2005). The 866.7 ha large reserve comprises several small forest fragments embedded in an agro-mosaic matrices (Coimbra-Filho and Câmara, 1996). The largest fragment, known as "Cuxio" ( $08^{\circ} 14^{\prime} 09^{\prime}$ " $\mathrm{S}, 35^{\circ} 03^{\prime}$ ' $45^{\prime}$ " W), where the sample site was established, is covered by mature rainforest and the most conserved fragment of the Nature Reserve, totalling 118.46 ha and a perimeter of 9,011 m. The climate is humid almost throughout the year, showing fewer rainfalls between October and December. Mean annual precipitation is $2450 \mathrm{~mm}$ and mean annual temperature is $25^{\circ} \mathrm{C}$ (SUDENE, 1978).

\subsection{Sampling}

Samplings were carried out once a month from November 2002 to October 2003. Eight different scent baits (filter paper, $10 \mathrm{~cm}$ diameter) were placed inside the forest fragment, about $200 \mathrm{~m}$ distant from the border, ca. two meters apart from each other and fixed at about $1.5 \mathrm{~m}$ height at tree trunks. The baits contained one of the following substances, known to be attractive to orchid bees after a pilot collection at the study site: benzyl acetate, benzyl benzoate, eugenol, $\beta$-ionone, 1,8-cineol (eucalyptol), methyl salicylate, skatole and vanillin. All baits were recharged every hour. The sampling period was from 08:00h to 13:00h, the main daily period of scent collection by male euglossine bees (Oliveira and Campos, 1996; Oliveira, 1999; Bezerra and Martins, 2001; Schlindwein and Wittmann, pers. observ.). The bees arriving on the baits were collected by two collectors, with entomological nets and killed with ethyl acetate. After each 30-minute interval of active collection per hour, we allowed another 30 minutes without disturbance to guarantee unhindered approach of new arriving males and of previously displaced males to return to the scented baits. To our experience, this procedure was especially important for the sampling of shy species. Because scent collection of males at baits lasts for several minutes, the pause was not disadvantageous for sampling bee abundance. Fieldwork, thus, totalled 60 hours, with 30 hours of active collection. The collected specimens were deposited at the Entomological Collections of the Federal Universities of Pernambuco (UFPE) and Minas Gerais (UFMG). Taxonomy follows Nemésio and Rasmussen (2011), Hinojosa-Díaz et al. (2012) and Nemésio and Engel (2012).

\subsection{Data analysis}

The species abundance data were presented with a rank-abundance where species were plotted according to their percentage cumulative abundance. We produced a species accumulation curve and to verify the sampling effort we used the first order Jackknife index, as $J_{a c k}=\mathrm{S}_{0}+\mathrm{f}_{1}$ $(\mathrm{N}-1 / \mathrm{N})$ and the Chao index, as $\mathrm{Chao}=\mathrm{S}_{0}+\left(\mathrm{f}_{1}^{2} / 2 \mathrm{f}_{2}\right)$, where $\mathrm{S}_{0}$ is the observed number of species, $\mathrm{f} 1$ and $\mathrm{f} 2$ are the numbers of species observed single or doubletons and $\mathrm{N}$ is the number of sites (Smith and van Belle, 1984; Chao, 1987). The analysis was performed with $\mathrm{R}$ program. Furthermore, 
we performed a linear correlation between abundance of bees and species richness of orchid bees. The analyses were performed with R program (version 3.1.1).

\section{Results}

Two thousand nine hundred and eight orchid bee males belonging to 23 species were collected during the 12 months of sampling at Gurjaú reserve. Species accumulation curves indicated a rapid increase in initial number of species caught (Figure 1). From the seventh sample, the curve plateaued and raised again in the last sample, after the capture 2815 individuals, when one exemplar of a new species was recorded. According to non-parametric estimators total species richness ranges

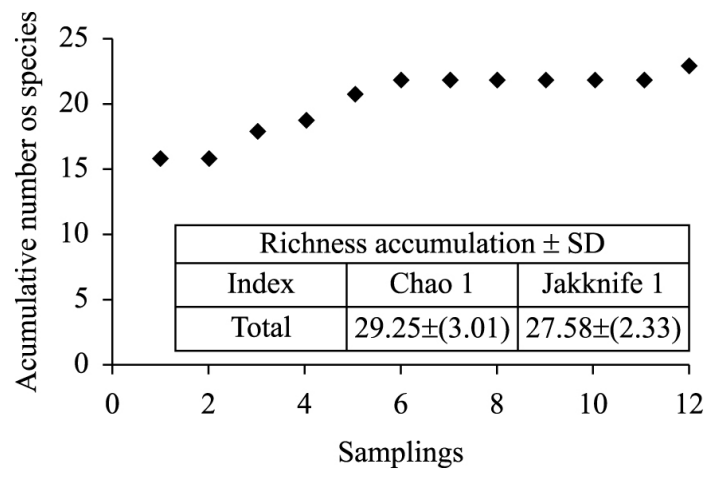

Figure 1. Species accumulation curve of euglossine bees sampled within 12 months in the Reserva Ecológica Gurjaú, Pernambuco, Brazil. from 27 to 29 species (Figure 1). About $50 \%$ of the bees were of Euglossa carolina Nemésio, 2009 that together with Eulaema nigrita Lepeletier, 1841 were the most abundant species, representing $75 \%$ of the collected individuals (Figure 2). Euglossa ignita Smith, 1874 and Eulaema marcii Nemésio, 2009 were the next most abundant species (Figure 2, Table 1). These common species were sampled at least in 10 of the 12 months of collection and five species in only one (Figure 3). Twelve species were represented by less than 10 specimens and four by singletons (Table 1).

The scent baits attracted between four (benzyl benzoate) and 13 ( $\beta$-ionone) species. Most individuals were recorded at the baits of $\beta$-ionone $(46.1 \%)$ and skatole $(23.6 \%)$. On the other hand, vanillin lured four (Eufriesea atlantica, Ef. surinamensis, Euglossa avicula, Exaerete smaragdina) and eugenol (Euglossa aratingae, Exaerete frontalis) two exclusive species but only 2.0 and $2.4 \%$ of the total number of euglossine males. Males of Eg. carolina were the most generalist in the use of pure scent compounds and were collected at all eight scent baits. Other species attracted to several scent baits were El. marcii (7 compounds), El. nigrita (7), El. atleticana (6), and Eg. ignita (6) (Table 1).

Euglossine abundance ranged from 93 bees collected in October 2003 to 657 bees collected in April 2003, with secondary peaks of activity in November and December 2002, May and August 2003. However, the months with higher abundance were not necessarily the most species rich months $\left(\mathrm{r}_{\text {Pearson }}=-0.04 ; \mathrm{P}=0.89\right)$. April 2003, for instance, the month with the most individuals recorded (657 specimens) accounted for only 11 species, while

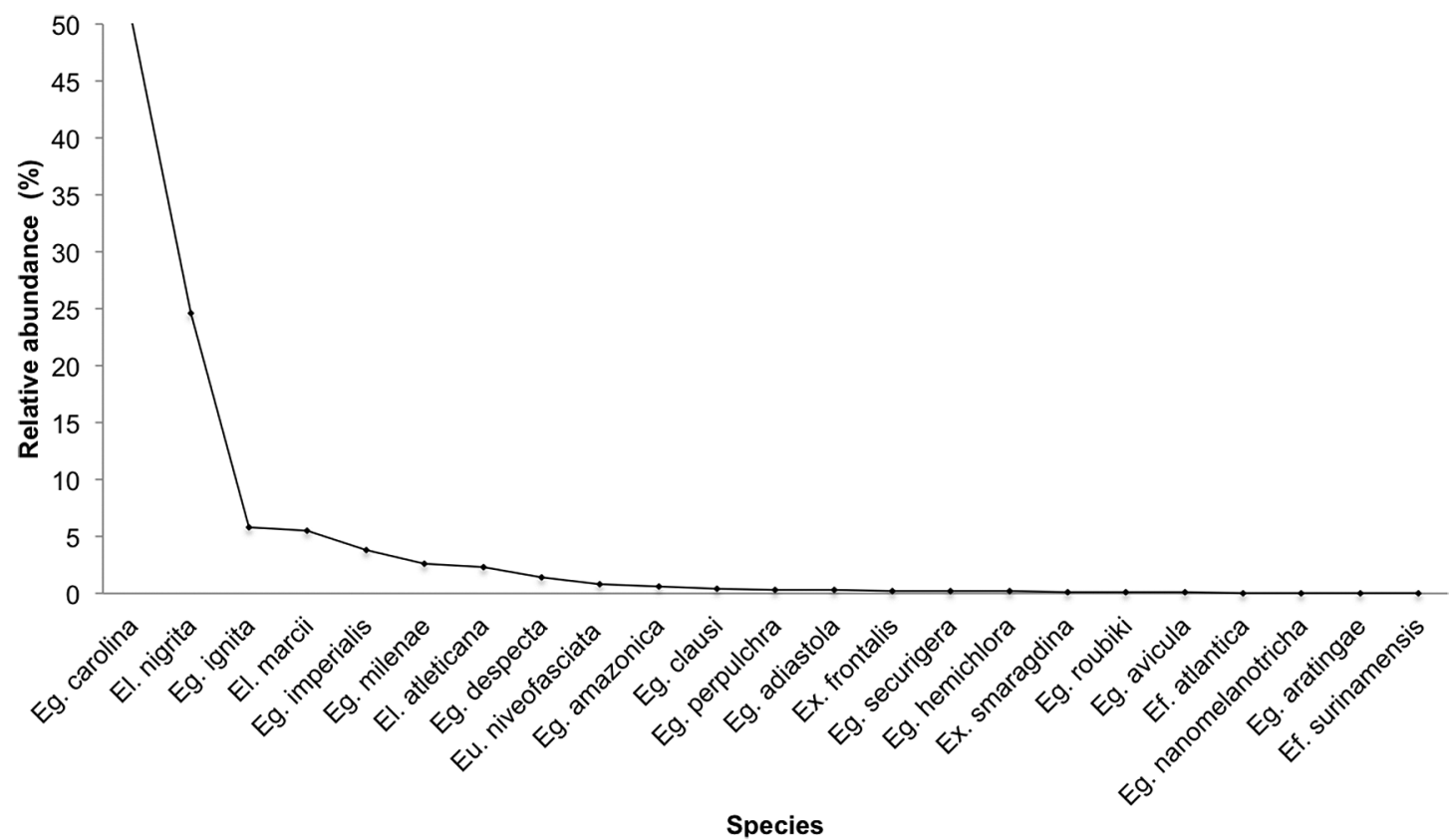

Figure 2. Relative abundance of orchid bees during a yearlong inventory in the Reserva Ecológica Gurjaú, Pernambuco, Brazil. 
Table 1. Number of specimens of each orchid bee species collected at eight different scent baits at the Reserva Ecológica Gurjaú, Pernambuco, Brazil, from November 2002 to October 2003. Recently described species, new combinations and their earlier treatments are: Ef. atlantica Nemésio, 2008: syn: Ef. ornata (Mocsáry, 1896); Eg. adiastola Hinojosa-Díaz, Nemésio \& Engel, 2012 - syn: Eg. augaspis Dressler, 1982; Eg. roubiki Nemésio, 2009 - syn: Eg. chalybeata Friese, 1925; Eg. amazonica Dressler, 1982 - syn: Eg. truncata Rêbelo \& Moure, 1996; Eg. aratingae Nemésio, 2009 - syn: Eg. townsendi Cockerell. Eg. carolina Nemésio, 2009 - syn: Eg cordata Linnaeus, 1758; Eg. clausi Nemésio \& Engel, 2012 - syn: Eg. crassipunctata Moure 1968; Eg. despecta Moure, 1968 - syn: Eg. violaceifrons Rêbelo \& Moure, 1996 [parte]; Eg. hemichlora Cockerell, 1917 - syn: Eg. gaianii Dressler, 1982; Eg. milenae Bembé, 2007 - syn: Eg. vialaceifrons = Rêbelo \& Moure, 1996 [parte]; Eg. nanomelanotricha Nemésio, 2009 - syn: Eg. melanotricha Moure, 1967 [parte]; El. atleticana Nemésio, 2009 - syn: El. flavescens (Friese, 1899); El. marcii Nemésio, 2009 - syn: El. cingulata (Fabricius, 1804); El. niveofasciata (Friese, 1899) - syn: El. bombiformis (Packard, 1869).

$\begin{array}{lllllllllll}\text { Species } & \text { B A } & \text { B B } & \boldsymbol{\beta} \text {-I } & \text { C } & \text { E } & \text { M S } & \text { S } & \text { V } \begin{array}{c}\text { Total } \\ \text { number of } \\ \text { individuals }\end{array}\end{array}$

\begin{tabular}{|c|c|c|c|c|c|c|c|c|c|}
\hline Eufriesea atlantica (Nemésio, 2008) & & & & & & & & 1 & 1 \\
\hline Eufriesea surinamensis (Linnaeus, 1758) & & & & & & & & 1 & 1 \\
\hline Euglossa (Euglossa) amazonica (Dressler, 1982) & & 1 & & 3 & 12 & 1 & 2 & & 19 \\
\hline Euglossa (Euglossa) aratingae (Nemésio, 2009) & & & & & 1 & & & & 1 \\
\hline Euglossa (Euglossa) avicula (Dressler, 1982) & & & & & & & & 2 & 2 \\
\hline Euglossa (Euglossa) carolina (Nemésio, 2009) & 19 & 25 & 1174 & 232 & 8 & 2 & 1 & 1 & 1462 \\
\hline Euglossa (Euglossa) despecta (Moure, 1968) & & & 3 & 15 & 11 & & 13 & & 42 \\
\hline Euglossa (Euglossa) hemichlora (Cockerell, 1917) & & & & & & 5 & & & 5 \\
\hline Euglossa (Euglossa) milenae (Bembé, 2007) & 1 & & 75 & & & & & & 76 \\
\hline $\begin{array}{l}\text { Euglossa (Euglossa) nanomelanotricha } \\
\text { (Nemésio, 2009) }\end{array}$ & & & 1 & & & & & & 1 \\
\hline Euglossa (Euglossa) securigera (Dressler, 1982) & & & 3 & & 4 & & & & 7 \\
\hline $\begin{array}{l}\text { Euglossa (Euglossella) adiastola (Hinojosa-Díaz, } \\
\text { Nemésio \& Engel, 2012) }\end{array}$ & & & 1 & 2 & 2 & 2 & & 1 & 8 \\
\hline $\begin{array}{l}\text { Euglossa (Euglossella) perpulchra (Moure and } \\
\text { Schlindwein, 2002) }\end{array}$ & 1 & & 7 & & & & & 1 & 9 \\
\hline Euglossa (Glossura) ignita (Smith, 1874) & 64 & 13 & 46 & 9 & & 37 & & 1 & 170 \\
\hline Euglossa (Glossura) imperialis (Cockerell, 1922) & & & 1 & 8 & 3 & 100 & & & 112 \\
\hline Euglossa (Glossura) roubiki (Nemésio, 2009) & & & & 1 & & 2 & & & 3 \\
\hline $\begin{array}{l}\text { Euglossa (Glossurella) clausi (Nemésio and } \\
\text { Engel, 2012) }\end{array}$ & & & 1 & 4 & & 1 & & 5 & 11 \\
\hline Eulaema (Apeulaema) marcii (Nemésio, 2009) & 86 & 2 & 19 & 2 & 18 & & 25 & 8 & 160 \\
\hline Eulaema (Apeulaema) nigrita (Lepeletier, 1841) & 14 & & 1 & 28 & 1 & 6 & 634 & 31 & 715 \\
\hline Eulaema (Eulaema) atleticana (Nemésio, 2009) & 25 & & 10 & 14 & 2 & 14 & & 2 & 67 \\
\hline Eulaema (Eulaema) niveofasciata (Friese, 1899) & & & & 2 & & 23 & & & 25 \\
\hline Exaerete frontalis (Guérin-Méneville, 1844) & & & & & 7 & & & & 7 \\
\hline Exaerete smaragdina (Guérin-Méneville, 1844) & & & & & & & & 4 & 4 \\
\hline Sum & 210 & 41 & 1342 & 320 & 69 & 193 & 675 & 58 & 2908 \\
\hline
\end{tabular}

$\mathrm{BA}=$ benzyl acetate $\mathrm{BB}=$ benzyl benzoate; $\beta$ - $\mathrm{I}=\beta$-ionone; $\mathrm{E}=$ eugenol; $\mathrm{C}=1,8$-cineole; $\mathrm{MS}=$ methyl salicylate; $\mathrm{S}=$ skatole and $\mathrm{V}=$ vanillin.

September (135 specimens) and October, the lowest individual number recorded per month (92), included a species richness of 15 and 14 species, respectively (Figure 2). Overall diversity was $H^{\prime}=2.29$ and evenness $\mathrm{E}=0.51$.

\section{Discussion}

\subsection{Faunistics and richness}

The euglossine fauna of the Gurjaú site is characterized by extraordinary high species richness when compared to other Atlantic Forest remnants in NE-Brazil (Rebêlo and Silva, 1999; Bezerra and Martins, 2001; Neves and Viana, 2003; Farias et al., 2008; Ramalho et al., 2013). The species accumulation curve indicates that the orchid bee community at Gurjaú is well represented, but also that after exhaustive sampling effort rare species may yet appear. Recorded species richness corresponds to 79 and $83 \%$ of that indicated by Chao1 and Jacknife1 estimators, respectively. Cordeiro et al. (2013) documented that 15 of 19 species (73\%) recorded in an Atlantic Forest remnant in São Paulo state were sampled in the first of a two-year sampling period. In our study, in the first month of sampling, already 


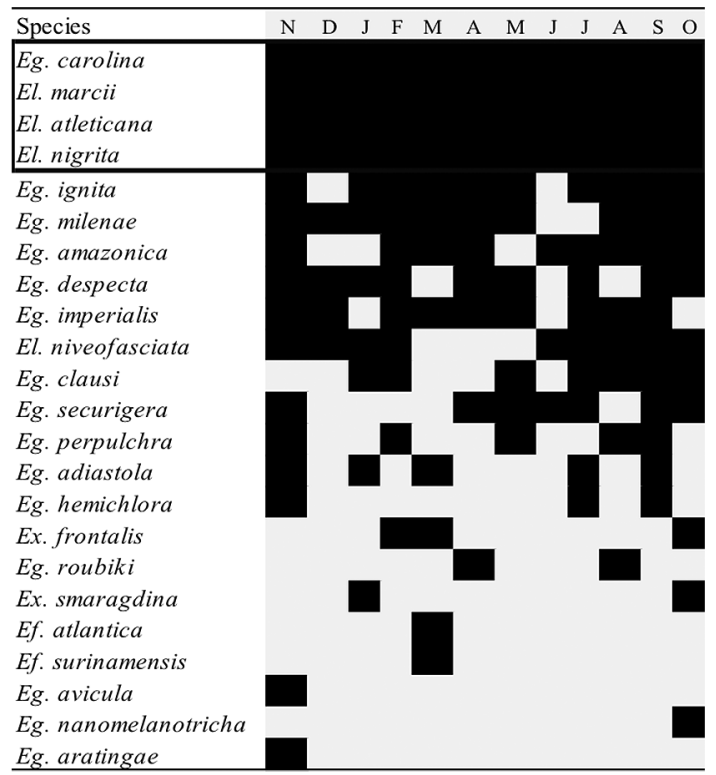

Figure 3. Monthly orchid bee abundance at Reserva Ecológica Gurjaú from November 2002 to October 2003. The dominant species were recorded throughout the year.

$65 \%$ of the orchid bee species were recorded, documenting the efficiency of the method. The here studied Euglossini assemblage is characterized by the striking dominance of the two probably most common orchid bee species of Brazil: Eg. carolina and El. nigrita, which were pointed out as abundant species also in other surveys within the Atlantic Forest (Ramalho et al., 2009; Aguiar and Gaglianone, 2012; Cordeiro et al., 2013; Ramalho et al., 2013). All species collected in the present study were already recorded in CEP in nearby areas (Darrault et al., 2006; Nemésio, 2010), except for Eufriesea surinamensis (Linnaeus, 1758), a common species in the Atlantic Forest south of the São Francisco river (Nemésio, 2009).

A similar high species richness of the Gurjaú site (23 species) within the Atlantic Forest was recorded also at the Nature Reserves "Estação Ecológica de Murici" (ESEC Murici) in the state of Alagoas (Nemésio, 2010), and at the "Reserva Particular do Patrimônio Natural Frei Caneca" (RPPN Frei Caneca) in the state of Pernambuco (Darrault et al., 2006), all part of CEP. Most yearlong euglossine surveys in the Atlantic Rainforest, however, revealed much lower species richness than the Gurjaú site (9-20 species) (Peruquetti et al., 1999; Bezerra and Martins, 2001; Tonhasca et al., 2002; Farias et al., 2008; Rosa et al., 2008; Ramalho et al., 2009; Aguiar and Gaglianone, 2012; Rocha-Filho and Garofalo, 2013 - two years of sampling). The species richness of the orchid bee fauna of the northern portion of the Atlantic Rainforest almost reaches that of the Amazon and Central American Rainforest (Nemésio and Silveira, 2007b).

\subsection{Dominant species}

The high abundance of Eg. carolina and El. nigrita, summing three quarter of the recorded males, is remarkable. These species and El. marcii are known to be tolerant to environmental disturbance, nest inside urban environments (Wittmann et al., 2000; Bezerra and Martins, 2001; Nemésio and Silveira, 2007a) and are one of the few euglossine species that occur in the open Caatinga (Zanella, 2000).

Curiously, males of only these three above mentioned species, out of a total of 16 species, could be experimentally lured to leave closed Atlantic Rainforest to collect fragrances at scent baits presented inside the sugarcane monoculture matrix that commonly surrounds the forest fragments of NE-Brazilian Atlantic Forest (Milet-Pinheiro and Schlindwein, 2005). The high abundance of these species, thus, may be related to their ability to leave a forest fragment to forage in another one, for example, when resources get scarce. The general abundance patterns of Northern Atlantic Rainforest euglossine communities show that Eg. carolina, El. nigrita and El. marcii are usually among the five dominant orchid bee species in this region under the present environmental conditions (Nemésio, 2009). However, we have no functional or ecological explication for the dominance of these species in these forest fragments, since the information on the natural history of these species, their environmental demands, like the relationships to pollen and nectar host plants, cleptoparasites, nesting and reproductive biology are poorly known. The ability of the two dominant species to nest in disturbed surroundings may be considered to explain the high abundance of these bees (López-Uribe et al., 2008).

Dominant species generally contribute most to ecosystem functions and are consistently present in the community over time (Smith and Knapp, 2003). In pollination systems, the most generalized bee species are usually network keystone-species that interact with a high number of host plants and connect otherwise unconnected subnetworks (González et al., 2010). In euglossine communities, we could expect that after habitat alterations, the common, and normally generalist species that resisted the habitat alterations are fundamental to maintain part of the local pollinator-plant interactions at least at short term. In future studies, it would be interesting through analyses of pollen grains adhering to the body surface of the bees, to investigate the role of these dominant species on the euglossine-plant interactions.

Our findings on the relationships of euglossine males to pure scent compounds do not provide an explication for the strong dominance of a few species of the local community of Euglossini. Considering that different pure euglossine-luring scent compounds may represent different perfume producing species (Knudsen et al., 2006), we expected that the more common species are attracted to more scent compounds than rare species, which should be related to their broader sensorial ability to recognize different scents of perfume flowers. On one hand, the most common species were in fact recorded at most scent baits, however, $80 \%$ (1174 individuals) of the males of 
Eg. carolina were attracted to $\beta$-ionone and $89 \%$ (634) of the males of El. nigrita to skatole. On the other hand, the eight males of the rare Eg. adiastola were recorded on five different scent baits and the 19 males of Eg. amazonica on a total of six. To better understand the relationships of male euglossine bees to floral perfumes and their sensory ability to smell specific scent compounds, it is necessary to apply chemo-ecological tools, for example to test for electrophysiological antennal responses of the different species (see for example Eltz et al., 2008).

\subsection{Conservation}

In the Center of Endemism Pernambuco only a few, in general, small forest fragments still remain nowadays. These last remaining areas are severely threatened, although in some of them an impressive diversity of life forms can still be found (e.g. Silva and Tabarelli, 2001; Uchoa Neto and Tabarelli, 2002). The situation of these areas is a matter of concern due to (i) the continued anthropogenic pressures still in course in the region (Olmos, 2005) and (ii) predicted climatic changes that can heavily impact the forest remnants (Williams et al., 2007), changing their suitability for many species, like the rare and endemic Eufriesea atlantica and Euglossa perpulchra. Therefore, every possible effort to preserve Atlantic Rainforest fragments should be made.

The euglossine species richness observed at the study site suggests that a 100 ha forest remnant can hold a considerable part of the orchid bee richness in the region. The survey of euglossine bees (Darrault et al., 2006) and other organisms (Pôrto et al., 2005) at 12 fragments in the CEP showed that the fauna of the largest forest remnant was not significantly richer or more diverse than the smaller ones within a local complex of forest fragments separated often less than $100 \mathrm{~m}$ by areas of varying soil use and conservation degree, which provide a permeable matrix for these long-distance pollinators. Males of Exaerete frontalis can forage on 42-115 ha of rainforest and fly up to $5 \mathrm{~km}$ away from their core areas (Wikelski et al., 2010). Males of common species (Eg. carolina, El. nigrita and El. marcii) were shown to be attracted to collect scents at least $500 \mathrm{~m}$ distant from forest fragments (Milet-Pinheiro and Schlindwein, 2005) but, on the other hand, are known to be site-constant foragers (López-Uribe et al., 2008). Orchid bees with well-developed dispersal capacities may thus maintain a certain degree of connectivity of the forest fragments (Ramalho et al., 2013). The small forest remnants like Gurjaú reserve can still hold viable populations of a subset of euglossine species of the original Atlantic Forest fauna and may also act as important centers of dispersion or be part of future corridors connecting restored forest fragments.

In this study we presented the species composition of Euglossini bees occurring in one of the few remnants of the highly perturbed Atlantic Forest in Pernambuco. The study contributes to future biogeographical studies providing new data of the geographical occurrence of euglossine species and faunistic information of a region considered as a key communication point of Amazonian and Atlantic forests during the Cenozoic (Prance, 1982). Despite several studies on euglossine faunas in Brazil, the biology of the group is so far not sufficiently known to present a conclusive explanation about the causes of the marked dominance of few common species in the assemblages. From a conservationist point of view, the outstanding species richness found in the study site reinforces the importance to maintain "biodiversity friendly" and connected forest remnants even if small and neighbouring cities.

\section{Acknowledgements}

We thank Airton Torres Carvalho, Gabriela Bieber, Jose Araújo Duarte Jr., Olivier Darrault and Paulo Milet-Pinheiro for their help in bee collection and preparation. André Nemésio kindly identified the bees and contributed with several valuable comments on manuscript. The Brazilian government, through the environmental departments IBAMA and ICMBio, provided the collecting permits. The study received financial support by MMA-PROBIO. RO and CS acknowledge grants provided by CNPq.

\section{References}

ACKERMAN, J.D., 1983. Diversity and seasonality of male euglossine bees (Hymenoptera: Apidae) in Central Panama. Ecology, vol. 64, no. 2, pp. 274-283. http://dx.doi.org/10.2307/1937075.

ACKERMAN, J.D., 1989. Geographic and seasonal variation in fragrance choices and preferences of male euglossine bees. Biotropica, vol. 21, no. 4, pp. 340-347. http://dx.doi.org/10.2307/2388284.

AGUIAR, W.M. and GAGLIANONE, M.C., 2012. Euglossine bee communities in small forest fragments of the Atlantic Forest, Rio de Janeiro state, southeastern Brazil (Hymenoptera, Apidae). Revista Brasileira de Entomologia, vol. 56, no. 2, pp. 210-219. http://dx.doi.org/10.1590/S0085-56262012005000018.

BEZERRA, C.P. and MARTINS, C.F., 2001. Diversidade de Euglossinae (Hymenoptera, Apidae) em dois fragmentos de Mata Atlântica localizados na região urbana de João Pessoa, Paraíba, Brasil. Revista Brasileira de Zoologia, vol. 18, no. 3, pp. 823-835. http://dx.doi.org/10.1590/S0101-81752001000300018.

CHAO, A., 1987. Estimating the population size for capturerecapture data with unequal catchability. Biometrics, vol. 43, no. 4, pp. 783-791. http://dx.doi.org/10.2307/2531532. PMid:3427163.

COIMBRA-FILHO, A.F. and CÂMARA, L.G., 1996. Os limites originais do bioma Mata Atlântica na região nordeste do Brasil. Rio de Janeiro: Fundação Brasileira para a Conservação da Natureza. 86 p.

CORDEIRO, G.D., BOFF, S., CAETANO, T.A., FERNANDES, P.C. and ALVES-DOS-SANTOS, I., 2013. Euglossine bees (Apidae) in Atlantic forest áreas of São Paulo, southeastern Brazil. Apidologie, vol. 44, no. 3, pp. 254-267. http://dx.doi.org/10.1007/ s13592-012-0176-3.

DARRAULT, R.O., MEDEIROS, P.C.R., LOCATELLI, E., LOPES, A.V., MACHADO, I.C. and SCHLINDWEIN, C., 2006. Abelhas Euglossini. In: K.C. PÔRTO, J.S. ALMEIDA-CORTEZ and M. TABARELLI, eds. Diversidade biológica e conservação da Floresta Atlântica ao norte do Rio São Francisco. Brasília: Ministério do Meio Ambiente, pp. 239-253. 
DODSON, C.H., DRESSLER, R.L., HILLS, H.G., ADAMS, R.M. and WILLIAMS, N.H., 1969. Biologically active compounds in orchid fragrances. Science, vol. 164, no. 3885, pp. 1243-1249. http://dx.doi.org/10.1126/science.164.3885.1243. PMid:17772561.

DRESSLER, R.L., 1982. Biology of the orchid bees (Euglossini). Annual Review of Ecology and Systematics, vol. 13, no. 1, pp. 373-394. http://dx.doi.org/10.1146/annurev.es.13.110182.002105.

ELTZ, T., ROUBIK, D.W. and LUNAU, K., 2005. Experiencedependent choices ensure species-specific fragrance accumulation in male orchid bees. Behavioral Ecology and Sociobiology, vol. 59, no. 1, pp. 146-156. http://dx.doi.org/10.1007/s00265-005-0021-z.

ELTZ, T., WHITTEN, W.M., ROUBIK, D.W. and LINSENMAIR, K.E., 1999. Fragrance collection, storage, and accumulation by individual male orchid bees. Journal of Chemical Ecology, vol. 25, no. 1, pp. 157-176. http://dx.doi.org/10.1023/A:1020897302355.

ELTZ, T., ZIMMERMANN, Y., PFEIFFER, C., PECH, J.R., TWELE, R., FRANCKE, W., QUEZADA-EUAN, J.J.G. and LUNAU, K., 2008. An olfactory shift is associated with male perfume differentiation and species divergence in orchid bees. Current Biology, vol. 18, no. 23, pp. 1844-1848. http://dx.doi. org/10.1016/j.cub.2008.10.049. PMid:19062287.

FARIA, L.R.R. and MELO, G.A.R., 2011. A new species of Eufriesea Cockerell (Hymenoptera, Apidae, Euglossina) from northeastern Brazil. Revista Brasileira de Entomologia, vol. 55, no. 1, pp. 35-39. http://dx.doi.org/10.1590/S0085-56262011000100007.

FARIAS, R.C.A.P., MADEIRA-DA-SILVA, M.C., PEREIRAPEIXOTO, M.H. and MARTINS, C.F., 2008. Composição e sazonalidade de espécies de Euglossina (Hymenoptera: Apidae) em mata e duna na Área de Proteção Ambiental da Barra do Rio Mamanguape, Rio Tinto, PB. Neotropical Entomology, vol. 37, no. 3, pp. 253-258. http://dx.doi.org/10.1590/S1519566X2008000300003. PMid:18641895.

GONZÁLEZ, A.M., DALSGAARD, B. and OLESEN, J.M., 2010. Centrality measures and the importance of generalist species in pollination networks. Ecological Complexity, vol. 7, no. 1, pp. 36-43. http://dx.doi.org/10.1016/j.ecocom.2009.03.008.

HINOJOSA-DÍAZ, I.A., NEMÉSIO, A. and ENGEL, M.S., 2012. Two new species of Euglossa from South America, with notes on their taxonomic affinities (Hymenoptera, Apidae). ZooKeys, vol. 221, no. 221, pp. 63-79. PMid:23129981.

JANZEN, D.H., DEVRIES, P.J., HIGGINS, M.L. and KIMSEY, L.S., 1982. Seasonal and site variation in Costa Rican euglossine bees at chemical baits in lowland deciduous and evergreen forests. Ecology, vol. 63, no. 1, pp. 66-74. http://dx.doi.org/10.2307/1937032.

KIMSEY, L.S., 1980. The behavior of male orchid bees (Apidae, Hymenoptera, Insecta) and question of leks. Animal Behaviour, vol. 28 , no. 4 , pp. 996-1004. http://dx.doi.org/10.1016/S00033472(80)80088-1.

KNUDSEN, J.T., ERIKSSON, R., GERSHENZON, J. and STAHL, B., 2006. Diversity and distribution of floral scents. Botanical Review, vol. 72, no. 1, pp. 1-120. http://dx.doi.org/10.1663/00068101(2006)72[1:DADOFS]2.0.CO;2.

LÓPEZ-URIBE, M.M., OI, C.A. and DEL LAMA, M.A., 2008. Nectar-foraging behaviour of euglossine bees (Hymenoptera: Apidae) in urban areas. Apidologie, vol. 39, no. 4, pp. 410-418. http://dx.doi.org/10.1051/apido:2008023.

MILET-PINHEIRO, P. and SCHLINDWEIN, C., 2005. Do euglossine males (Apidae, Euglossini) leave tropical rainforest to collect fragrances in sugarcane monocultures? Revista Brasileira de Zoologia, vol. 22, no. 4, pp. 853-858. http://dx.doi.org/10.1590/ S0101-81752005000400008.

MOURE, J.S. and SCHLINDWEIN, C., 2002. Uma nova espécie de Euglossa (Euglossella) Moure do Nordeste do Brasil (Hymenoptera, Apidae). Revista Brasileira de Zoologia, vol. 19, no. 2, pp. 585588. http://dx.doi.org/10.1590/S0101-81752002000200014.

NEMÉSIO, A., 2009. Orchid bees (Hymenoptera: Apidae) of the Brazilian Atlantic Forest. Zootaxa, vol. 2041, pp. 1-242.

NEMÉSIO, A., 2010. The orchid bee fauna (Hymenoptera: Apidae) of a forest remnant in northeastern Brazil, with new geographic records and an identification key to the known species of the Atlantic Forest of northeastern Brazil. Zootaxa, vol. 2656, pp. 55-66.

NEMÉSIO, A. and ENGEL, M.S., 2012. Three new cryptic species of Euglossa from Brazil (Hymenoptera, Apidae). ZooKeys, vol. 222, no. 222, pp. 47-68. PMid:23129986.

NEMÉSIO, A. and RASMUSSEN, C., 2011. Taxonomic issues in the orchid bees (Hymenoptera: Apidae: Euglossina), and an updated catalogue. Zootaxa, vol. 3006, pp. 1-42.

NEMÉSIO, A. and SILVEIRA, F.A., 2007a. Orchid bee fauna (Hymenoptera: Apidae: Euglossina) of Atlantic Forest fragments inside an urban area in southeastern Brazil. Neotropical Entomology, vol. 36, no. 2, pp. 186-191. http://dx.doi.org/10.1590/S1519566X2007000200003. PMid:17607450.

NEMÉSIO, A. and SILVEIRA, F.A., 2007b. Diversity and distribution of orchid bees (Hymenoptera: Apidae) with a revised checklist of species. Neotropical Entomology, vol. 36, no. 6, pp. 874-888. http://dx.doi.org/10.1590/S1519-566X2007000600008. PMid:18246261.

NEMÉSIO, A. and SILVEIRA, F.A., 2010. Forest fragments with larger core areas better sustain diverse orchid bee faunas (Hymenoptera: Apidae). Neotropical Entomology, vol. 39, no. 4, pp. 555-561. http://dx.doi.org/10.1590/S1519-566X2010000400014. PMid:20877991.

NEVES, E.L. and VIANA, B.F., 2003. A fauna de abelhas da subtribo Euglossina (Hymenoptera, Apidae) do Estado da Bahia, Brasil. In: G.A.R. MELO and I.A. SANTOS, eds. Apoidea Neotropica: homenagem aos 90 anos de Jesus Santiago Moure. Criciúma: UNESC.

OLIVEIRA, M.L. and CAMPOS, L.A.O., 1996. Preferências por estratos florestais e por substâncias odoríferas em abelhas Euglossinae (Hymenoptera, Apidae). Revista Brasileira de Zoologia, vol. 13, no. 4, pp. 1075-1085. http://dx.doi.org/10.1590/ S0101-81751996000400025.

OLIVEIRA, M.L., 1999. Sazonalidade e horário de atividade de abelhas Euglossinae (Hymenoptera, Apidae), em florestas de terra firme na Amazônia Central. Revista Brasileira de Zoologia, vol. 16, no. 1, pp. 83-90. http://dx.doi.org/10.1590/ S0101-81751999000100003.

OLMOS, F., 2005. Aves ameaçadas, prioridades e políticas de conservação no Brasil. Natureza \& Conservação, vol. 3, pp. 21-42.

PERUQUETTI, R.C., CAMPOS, L.A.O., COELHO, C.D.P.C., ABRANTES, C.V.M. and LISBOA, L.C.O., 1999. Abelhas Euglossini (Apidae) de áreas de Mata Atlântica: abundância, riqueza e aspectos biológicos. Revista Brasileira de Zoologia, vol. 16, pp. 101-118. http://dx.doi.org/10.1590/S0101-81751999000600012.

PORTO, K.C., ALMEIDA-CORTEZ, J. and TABARELLI, M., 2005. Diversidade biológica e conservação da Floresta Atlântica ao norte do Rio São Francisco. Brasília: Ministério do Meio Ambiente. 363 p. 
POWELL, A.H. and POWELL, G.V.N., 1987. Population dynamics of male euglossine bees in Amazonian forest fragments. Biotropica, vol. 19, no. 2, pp. 176-179. http://dx.doi.org/10.2307/2388742.

PRANCE, G.T., 1982. Forest refuges: evidence from woody angiosperms. In: G.T. PRANCE, ed. Biological diversification in the tropics. New York: Columbia University Press, pp. 137-158.

RAMALHO, A.V., GAGLIANONE, M.C. and OLIVEIRA, M.L., 2009. Comunidades de abelhas Euglossina (Hyumenoptera, Apidae) em fragmentos de Mata Atlântica no Sudeste do Brasil. Revista Brasileira de Entomologia, vol. 53, no. 1, pp. 95-101. http://dx.doi.org/10.1590/S0085-56262009000100022.

RAMALHO, M., ROSA, J.F., DANTAS E SILVA, M., SILVA, M. and MONTEIRO, D., 2013. Spatial distribution of orchid bees in a rainforest/rubber agro-forest mosaic: habitat use or connectivity. Apidologie, vol. 44, no. 4, pp. 385-403. http://dx.doi.org/10.1007/ s13592-012-0189-y.

REBÊLO, J.M. and SILVA, F.S., 1999. Distribuição das abelhas Euglossini (Hymenoptera: Apidae) no Estado do Maranhão, Brasil. Anais da Sociedade Entomológica do Brasil, vol. 28, no. 3, pp. 389-401. http://dx.doi.org/10.1590/S0301-80591999000300003.

RIBEIRO, M.C., METZGER, J.P., MARTENSEN, A.C., PONZONI, F.J. and HIROTA, M.M., 2009. The Brazilian Atlantic Forest: how much is left, and how is the remaining forest distributed? Implications for conservation. Biological Conservation, vol. 142, no. 6, pp. 1141-1153. http://dx.doi.org/10.1016/j.biocon.2009.02.021.

ROCHA-FILHO, L.C. and GARÓFALO, C.A., 2013. Community ecology of euglossine bees in the coastal Atlantic Forest of São Paulo state, Brazil. Journal of Insect Science, vol. 13, no. 23, pp. 1-23. http://dx.doi.org/10.1673/031.013.2301. PMid:23901873.

ROSA, J.F., OLIVEIRA, J.P.L., GURGEL, Z.E.R., DUARTE, C.S.A. and RAMALHO, M., 2008. Estratificação da atividade de coleta de essência por abelash Euglossina em aum remanescente de Mata Atlântica na Reserva da Michelin, Bahia, Brasil. Sitientibus Série Ciências Biológicas, vol. 8, pp. 307-310.

ROUBIK, D.W. and HANSON, P.E., 2004. Orchid bees: biology and field guide. San Jose: INBIO. $370 \mathrm{p}$.

ROUBIK, D.W., 2001 [viewed 20 February 2014 ]. Up's and down's in pollinator populations: when is there a decline? Conservation Ecology [online], vol. 5, no. 1, pp. 2. Available from: http://www. consecol.org/vol5/issl/art2

SCHLINDWEIN, C., 2000. A importância de abelhas especializadas na polinização de plantas nativas e conservação do meio ambiente. In: Anais do IV Encontro Sobre Abelhas, 2010, Ribeirão Preto. Ribeirão Preto: Universidade de São Paulo, pp. 131-141.

SILVA, J.M.C. and TABARELLI, M., 2000. Tree species impoverishment and the future flora of the Atlantic Forest of northeast Brazil. Nature, vol. 404, no. 6773, pp. 72-74. http:// dx.doi.org/10.1038/35003563. PMid:10716443.
SILVA, J.M.C. and TABARELLI, M., 2001. The future of Atlantic forest in northeastern Brazil. Conservation Biology, vol. 15, no. 4, pp. 819-820. http://dx.doi.org/10.1046/j.1523-1739.2001.00014-4.x.

SMITH, M.D. and KNAPP, A.K., 2003. Dominant species maintain ecosystem function with non-random species loss. Ecology Letters, vol. 6 , no. 6, pp. 509-517. http://dx.doi.org/10.1046/j.14610248.2003.00454.x

SMITH, E. and VAN BELLE, G., 1984. Nonparametric estimation of species richness. Biometrics, vol. 40, no. 1, pp. 119-129. http:// dx.doi.org/10.2307/2530750.

SUPERINTENDÊNCIA DO DESENVOLVIMENTO DO NORDESTE - SUDENE, 1978. Inventário hidrogeológico básico do nordeste. Recife: Sudene. 184 p.

TONHASCA, A.J.R., BLACKMER, J.L. and ALBUQUERQUE, G.O.S., 2002. Abundance and diversity of euglossine bees in the fragmented landscape of the Brazilian Atlantic Forest. Biotropica, vol. 34, no. 3, pp. 416-422. http://dx.doi.org/10.1111/j.1744-7429.2002. tb00555.x

UCHOA NETO, C.A. and TABARELLI, M., 2002. Diagnóstico e estratégia de conservação do Centro de Endemismo Pernambuco. Recife: Conservation International do Brasil. 69 p.

VOGEL, S., 1963. Das sexuelle anlockungsprinzip der catasetinen und stanhopeen-blüten und die wahre funktion ihres sogenannten futtergewebes. Österreichische Botanicheskii Zhurnal, vol. 110, no. 2, pp. 308-337.

VOGEL, S., 1966. Parfümsammelnde bienen als bestäuber von orchidaceen und Gloxinia. Österreichische Botanische Zeitschrift, vol. 113, pp. 302-361.

WIKELSKI, M., MOXLEY, J., EATON-MORDAS, A., LÓPEZURIBE, M.M., HOLLAND, R., MOSKOWITZ, D., ROUBIK, D.W. and KAYS, R., 2010. Large-range movements of Neotropical orchid bees observed via radio telemetry. PLoS One, vol. 5, no. 5, pp. e10738. http://dx.doi.org/10.1371/journal.pone.0010738. PMid:20520813.

WILLIAMS, J.W., JACKSON, S.T. and KUTZBACH, J.E., 2007. Projected distributions of novel and disappearing climates by 2100 AD. Proceedings of the National Academy of Sciences of the United States of America, vol. 104, no. 14, pp. 5738-5742. http://dx.doi.org/10.1073/pnas.0606292104. PMid:17389402.

WITTMANN, D., HAMM, A., MACHADO, I.C., SCHIFFLER, D. and SCHLINDWEIN, C., 2000. Artenvielfalt von Euglossinen in einem Regenwald-Fragment und angrenzenden landwirtschaftlichen Nutzflächen in Pernambuco, Brasilien. In: T. OSTEN, ed. Beiträge der Hymenopterologen-Tagung in Stuttgart. Eberswalde: Deutschen Entomologischen Institut, pp. 67-70.

ZANELLA, F.C.V., 2000. The bees of Caatinga: a list of species and comparative notes regarding their distribution. Apidologie, vol. 31, no. 5, pp. 579-592. http://dx.doi.org/10.1051/apido:2000148. 